\title{
Characterisation of the size and composition of circulating immune complexes in patients with rheumatoid arthritis
}

\author{
R A Mageed, J R Kirwan, P W Thompson, D A McCarthy, E J Holborow
}

\begin{abstract}
The size and composition of circulating immune complexes in the sera of patients with rheumatoid arthritis (RA) were studied in relation to different manifestations of the disease. Circulating immune complexes from the sera of 94 patients ( 50 with extra-articular disease) and 10 matched controls were fractionated by sucrose density gradient ultracentrifugation. The composition, immunoglobulin and rheumatoid factor (RF) concentrations within each of the fractions were determined by a sensitive enzyme linked immunosorbent assay (ELISA).

Intermediate size (14S-21S) IgG complexes containing RF activity and $22 S$ IgG-IgM RF complexes were found in the sera of $\mathbf{4 0}$ patients with $R A$, while intermediate size complexes of self associated IgG KF and larger size complexes ( $>22 S$ ) of IgG RF and IgM RF were associated with extra-articular features of RA ( $50 \%$ of extra-articular disease). Complexes containing IgA were found in the sera of many patients with $R A$, and dimeric IgA RF mainly in patients with extra-articular disease.

These results support the view that whereas small size circulating immune complexes are of no primary pathogenic importance in synovitis, large size $(>22 S)$ circulating immune complexes may play a role in extra-articular disease in RA. Current understanding of the formation of large complexes provides a biological explanation for their occurrence and effects.
\end{abstract}

Immune complexes are thought to play a part in the pathogenesis of synovitis and in the adverse immunological events of autoimmune diseases such as systemic lupus erythematosus and rheumatoid arthritis (RA). ${ }^{12}$ Immune complexes have been demonstrated in synovial tissue, ${ }^{3}$ synovial neutrophils, ${ }^{4}$ synovial fluid, ${ }^{56}$ and $\operatorname{sera}^{7}$ from patients with RA, and these findings have stimulated the development of numerous assay procedures for their measurement. In RA the detection and measurement of circulating immune complexes has been seen as a potential laboratory guide to disease activity and as an indicator of impending or deteriorating extra-articular disease, ${ }^{8-11}$ though their pathological significance remains poorly understood.

In experimental immune complex disease in animals the pathogenic effect of circulating immune complexes seemed to be dependent on their size and composition. ${ }^{12}$ In human systemic lupus erythematosus the presence or absence of different sizes of circulating immune complexes has been found to correlate with different complications of disease, such as renal involvement, ${ }^{13}$ though others disagree on the details of these findings. ${ }^{14}$

In RA synovial fluid immune complexes were found to be of both intermediate $(6 S-19 S)$ and large (22S-30S) size and to consist of IgG bound to IgG rheumatoid factor (RF). ${ }^{15} 16$ In serum, complexes of $22 \mathrm{~S}$ size have been detected by analytical ultracentrifugation, ${ }^{57}$ leading to the suggestion that these might consist of one molecule of IgM RF bound to five molecules of IgG. ${ }^{16}$ Pope et al demonstrated 7S-19S complexes of non-complement fixing self associated IgG RF in the sera of three patients with RA, ${ }^{17}$ and Moller $e t$ al identified similar intermediate size circulating immune complexes in four of 11 patients. ${ }^{18}$

It would be of interest to elucidate further the nature of serum immune complexes in RA and to relate the size of the complexes and their RF content to clinical manifestations of the disease. We used ultracentrifugation of serum followed by IgA, IgG, and IgM class specific enzyme linked immunosorbent assay (ELISA) measurement of immunoglobulins and RF in different fractions to investigate this problem.

\section{Patients and methods}

PATIENTS

Of 94 patients with definite or classical RA (American Rheumatism Association criteria ${ }^{19}$ ), 26 were recruited by a single rheumatologist (JRK), together with 10 normal controls matched for age (within 5 years) and sex. Laboratory studies were conducted without knowledge of their clinical status. On the basis of data obtained from this well defined group a further 68 serum samples supplied by different rheumatologists were examined. Results from these two sets of patients were almost identical and have been amalgamated here. All the patients, taken together, included 44 with articular disease (group A) and 50 with extraarticular disease (group EA) (table 1). These included 21 patients with nodules only, nine with vasculitis only, and six with nodules and vasculitis. A further six patients with vasculitis had a range of other complications, including pericarditis (two), episcleritis (one), scleritis (two), and pulmonary fibrosis (one). Four patients had amyloid and a further four had Sjögren's syndrome. Disease activity (none/ mild/moderate/severe), radiographic erosions in the hands (present/absent), and treatment were 
Table 1 Patient characteristics

\begin{tabular}{|c|c|c|}
\hline & $\begin{array}{l}\text { Group } A \\
\text { Articular disease } \\
(n=44)\end{array}$ & $\begin{array}{l}\text { Group EA } \\
\text { Extra-articular disease } \\
(n=50)\end{array}$ \\
\hline $\begin{array}{l}\text { Age (years) } \\
\text { Sex (M/F) } \\
\text { Disease duration (years) } \\
\text { Age at onset of symptoms (years) } \\
\text { Disease activityt }\end{array}$ & $\begin{array}{l}55(13) \\
8 / 36 \\
10(9) \\
45(14)\end{array}$ & $\begin{array}{l}59(12) \\
24 / 26 \\
12(10) \\
46(16)\end{array}$ \\
\hline $\begin{array}{l}\text { Inactive } \\
\text { Mild } \\
\text { Moderate } \\
\text { Severe } \\
\text { Erosions (yes/no) } \ddagger \\
\text { Positive latex test for rheumatoid factor } \\
\text { Treatment }\end{array}$ & $\begin{array}{l}6 \\
13 \\
17 \\
8 \\
32 / 12 \\
37\end{array}$ & $\begin{array}{l}7 \\
15 \\
20 \\
8 \\
46 / 4 \\
47\end{array}$ \\
\hline $\begin{array}{l}\text { None } \\
\text { 2nAIDS only } \\
\text { 3rd line drugs } \\
\text { 3rd drugs }\end{array}$ & $\begin{array}{r}7 \\
14 \\
18 \\
5\end{array}$ & $\begin{array}{r}2 \\
9 \\
9 \\
30\end{array}$ \\
\hline
\end{tabular}

${ }^{*}$ Mean (SD) as reported by managing doctor.

+Disease activity represents the overall nature of the disease at the time serum samples were taken, assessed on the basis of articular index, duration of morning stiffness, pain, number of joints

affected, and the erythrocyte sedimentation rate.

†Definite erosion established by radiography.

\$NSAID = non-steroidal anti-inflammatory drug.

Penicillamine, gold, or antimalarial drugs.

शCytotoxic drugs or steroids, or both.

recorded by the clinician managing the patient. Normal controls are designated group $\mathrm{C}$.

Clq BINDING ASSAY

The Clq binding assay of Zubler et $a l^{20}$ was used, modified according to Bourke et al. ${ }^{21}$

Clq SOLID PHASE ELISA

The Clq solid phase assay was that described by Hay et al, ${ }^{22}$ modified for an ELISA. Bound immune complexes were disclosed with horseradish peroxidase conjugated goat $\mathrm{F}(\mathrm{ab})_{2}$ antihuman $\gamma, \alpha$, or $\mu$ heavy chain antibodies (Kallestad Diagnostics, Texas, USA).

The results were expressed in immune complex units according to the following formula as suggested by Wager et $a l^{23}$ :

Immune complex units $=(\mathrm{S} 492-\mathrm{X} 492) / \mathrm{SD}$

where $\mathrm{S} 492=$ absorbance of the test sample at $492 \mathrm{~nm}$; X492=mean absorbance of 10 normal human sera tested on the same plate; $\mathrm{SD}=$ standard deviation of the absorbance of the 10 normal sera.

SOLID PHASE ANTI-C3 ASSAY

Solid phase anti-C3 was determined by an ELISA with the solid phase sensitised with goat $\mathrm{F}(\mathrm{ab})_{2}$ antihuman C3 (Cappel Laboratories, Cochranvilles, PA, USA) at $14 \mu \mathrm{g} / \mathrm{ml}$ and 100 $\mu \mathrm{l} /$ well in phosphate buffered saline. Parallel duplicate wells sensitised with normal goat $\mathrm{F}(\mathrm{ab})_{2}$ were used as controls. The results were recorded as immune complex units as described for the Clq solid phase assay after subtracting optical density values for binding to normal goat $\mathrm{F}(\mathrm{ab})_{2}$ from that for binding to anti-C3 sensitised wells.

ELISA FOR THE MEASUREMENT OF RHEUMATOID FACTORS AND IMMUNOGLOBULINS

Rheumatoid factor was measured as described in detail elsewhere. ${ }^{24}$ Briefly, ELISA microtitre plates sensitised with rabbit gammaglobulins (at $50 \mu \mathrm{g} / \mathrm{ml}$ and $45 \mu \mathrm{l} /$ well) in phosphate buffered saline were used to measure $\operatorname{IgG}, \operatorname{IgA}$, and $\operatorname{IgM}$ RFs by reference to pooled RA sera with known concentrations of RF as measured by nephelometry and haemagglutination.

For measurement of immunoglobulins in sera and sucrose gradient fractions a similar approach was used with plates sensitised with $\mathrm{F}(\mathrm{ab})_{2}$ of antisera to $\gamma, \alpha$, and $\mu$ heavy chains (Kallestad Diagnostics, Texas, USA).

\section{SUCROSE DENSITY GRADIENT CENTRIFUGATION}

Sucrose density gradient centrifugation was carried out as described in detail by McCarthy $e t$ al. ${ }^{25}$ Briefly, sucrose gradients $(10-30 \% \mathrm{w} / \mathrm{v})$ were prepared in $16.5 \mathrm{ml}$ polycarbonate tubes with phosphate buffered saline $\mathrm{pH} 7 \cdot 4$ as the base buffer, and $500 \mu \mathrm{l}$ samples of serum, which had been diluted 1:2 with the same buffer, were layered on top of the gradient.

Sucrose gradients $(10-30 \% \mathrm{w} / \mathrm{v})$ prepared using $0 \cdot 105 \mathrm{M}$ glycine- $\mathrm{HCl}$ buffer and overlayed with the same volume of serum were centrifuged in parallel to assess the nature of circulating immune complexes in each fraction.

The gradients were centrifuged at $4^{\circ} \mathrm{C}$ for 19 hours at $23500 \mathrm{rpm}$ in an MSE 25 ultracentrifuge and fractionated by flotation ( $60 \%$ sucrose) using an ISCO fractionator into 25 fractions of $0.6 \mathrm{ml}$. Fractions from the acid glycine- $\mathrm{HCl}$ gradients were immediately neutralised to $\mathrm{pH}$ 7.4 by adding $0.6 \mathrm{ml}$ of $0.2 \mathrm{M} \mathrm{Na} \mathrm{Na}_{2} \mathrm{HPO}_{4}$ solution. The mean sedimentation coefficient of each fraction was determined as described by McCarthy et al. ${ }^{25}$ Fractions comprising 7S, 8S-13S, 14S-21S, 22S-30S, and >30S were pooled and used in the various assays.

\section{STATISTICAL ANALYSIS}

One way analysis of variance was used to test for trends in relation to clinical status of the groups. Student's $t$ test was used to examine the differences between each pair of groups.

\section{Results}

RHEUMATOID FACTOR AND CIRCULATING IMMUNE COMPLEX CONCENTRATIONS

In the 44 patients with articular disease alone raised concentrations of IgG RF, IgA RF, and IgM RF were found in $29(66 \%), 27(61 \%)$, and $40(91 \%)$ patients respectively. For the 50 patients with extra-articular disease raised concentrations of RF were noted in 44 (88\%), 42 $(84 \%)$, and 47 (94\%) (table 2).

Circulating immune complexes were raised in most patients. Although different assays gave slightly different results, circulating immune complexes were raised more commonly in extraarticular disease $(98 \%, 76 \%$, and $62 \%$ by $\mathrm{Clq}$ binding assay, $\mathrm{Clq}$ solid phase, and anti-C3 assays; see table 2) than in articular disease (59\%, 37\%, and 20\%). This was true for all three isotypes measured.

When serum was fractionated by density gradient centrifugation (table 3 , columns 4-8) 
Table 2 Rheumatoid factor $(R F)$ and circulating immune complex concentrations and their prevalence in controls $(C)$ and patients with rheumatoid arthritis with articular $(A)$ and extra-articular $(E A)$ disease

\begin{tabular}{|c|c|c|c|c|c|c|}
\hline & \multicolumn{2}{|c|}{ Group $C(n=10)$} & \multicolumn{2}{|c|}{ Group $A(n=44)$} & \multicolumn{2}{|c|}{ Group $E A(n=50)$} \\
\hline & Mean $(S D)$ & $\%$ Positive & Mean $(S D)$ & $\%$ Positive & Mean (SD) & $\%$ Positive* \\
\hline $\begin{array}{l}\text { RF† } \\
\text { IgG } \\
\text { IgA } \\
\text { IgM } \\
\text { Any combination }\end{array}$ & $\begin{array}{ll}1 \cdot 2 & (0 \cdot 8) \\
0 \cdot 4 & (0 \cdot 7) \\
2 \cdot 0 & (2 \cdot 1) \\
& -\end{array}$ & $\begin{array}{r}10 \\
0 \\
0 \\
10\end{array}$ & $\begin{array}{cc}2 \cdot 8 & (2 \cdot 9) \\
2 \cdot 6 & (3 \cdot 0) \\
4 \cdot 0 & (4 \cdot 1) \\
& -\end{array}$ & $\begin{array}{l}66 \\
61 \\
91 \\
91\end{array}$ & $\begin{array}{cc}3 \cdot 5 & (4 \cdot 0) \\
3 \cdot 5 & (4 \cdot 0) \\
5 \cdot 0 & (5 \cdot 4) \\
& \end{array}$ & $\begin{array}{l}88 \\
84 \\
94 \\
96\end{array}$ \\
\hline Clq binding assay $\ddagger$ & $4 \cdot 5 \quad(1 \cdot 7)$ & $\mathbf{0}$ & $21 \cdot 0 \quad(19)$ & 59 & $50 \cdot 0$ & 98 \\
\hline $\begin{array}{l}\text { Clq solid phasef } \\
\text { IgG } \\
\text { IgA } \\
\text { IgM } \\
\text { Any combination }\end{array}$ & $\begin{aligned} & 0.04(0.5) \\
&-1.0(0.5) \\
& 0.8(1.1) \\
&-\end{aligned}$ & $\begin{array}{l}0 \\
0 \\
0 \\
0\end{array}$ & $\begin{array}{ll}1 \cdot 4 & (2 \cdot 7) \\
0 \cdot 1 & (2 \cdot 1) \\
0.6 & (2 \cdot 0) \\
& -\end{array}$ & $\begin{array}{r}37 \\
16 \\
9 \\
37\end{array}$ & $\begin{array}{ll}2.3 & (3.0) \\
2.0 & (3.1) \\
0.9 & (1.8) \\
& -\end{array}$ & $\begin{array}{l}60 \\
46 \\
40 \\
76\end{array}$ \\
\hline $\begin{array}{l}\text { Anti-C3 assay } \$ \\
\text { IgG } \\
\text { IgA } \\
\text { IgM } \\
\text { Any combination }\end{array}$ & $\begin{array}{cc}-0.7 & (1.5) \\
-1.7 & (0.5) \\
0.9 & (1.8) \\
--\end{array}$ & $\begin{array}{l}0 \\
0 \\
0 \\
0\end{array}$ & $\begin{aligned} 0.2 & (1 \cdot 6) \\
-1.1 & (2 \cdot 1) \\
0.1 & (1 \cdot 2) \\
& -\end{aligned}$ & $\begin{array}{r}16 \\
9 \\
11 \\
20\end{array}$ & $\begin{array}{ll}1.6 & (2 \cdot 4) \\
0.3 & (3 \cdot 0) \\
0.3 & (2 \cdot 2) \\
& -\end{array}$ & $\begin{array}{l}46 \\
18 \\
14 \\
62\end{array}$ \\
\hline
\end{tabular}

*Percentage of individual values above the upper limit of normal (defined as mean +2SD for all subjects).

†In $\log _{10} \mathrm{ng} / \mathrm{ml}$.

†Percentage of total trichloroacetic acid precipitable ${ }^{125} \mathrm{I}-\mathrm{Clq}$

Śln immune complex units (IC).

Table 3 Distribution of immunoglobulin isotypes after sucrose density gradient ultracentrifugation. Values are given as mean $(S D)$

\begin{tabular}{|c|c|c|c|c|c|c|c|}
\hline \multirow{3}{*}{$\begin{array}{l}\text { Isotype } \\
\overline{\text { IgG }}\end{array}$} & \multirow{3}{*}{$\begin{array}{l}\begin{array}{l}\text { Patient } \\
\text { group }\end{array} \\
\text { C } \\
\text { A } \\
\text { EA }\end{array}$} & \multirow{2}{*}{$\begin{array}{l}\text { Whole serum } \\
\text { concentration } \\
(\mathrm{mg} / \mathrm{ml})\end{array}$} & \multicolumn{5}{|c|}{ Proportion (\%) in gradient zones indicated } \\
\hline & & & $\overline{7 S}$ & $8 S-13 S$ & $14 S-21 S$ & $22 S-30 S$ & $>30 S$ \\
\hline & & $\begin{array}{r}8.8(1 \cdot 8) \\
11.9(3.9)^{*} \\
14.2(11 \cdot 3)^{*}\end{array}$ & $\begin{array}{l}76 \cdot 4(4 \cdot 5) \\
74 \cdot 6(6 \cdot 6) \\
71 \cdot 4(6 \cdot 6)^{*} \dagger\end{array}$ & $\begin{array}{l}18 \cdot 1(0 \cdot 7) \\
19 \cdot 1(4 \cdot 9) \\
20 \cdot 7(4.9)\end{array}$ & $\begin{array}{l}1.9(0.7) \\
3.3(1 \cdot 8)^{*} \\
4.3(2 \cdot 5)^{*} \dagger\end{array}$ & $\begin{array}{l}1.1(0.3) \\
1.2(1.0) \\
1.4(0.9)\end{array}$ & $\begin{array}{l}1.3(1.2) \\
1.8(0.8) \\
1.9(0.8)\end{array}$ \\
\hline IgA & $\begin{array}{l}\text { C } \\
\text { A } \\
\text { EA }\end{array}$ & $\begin{array}{ll}1.8 & (0.8) \\
3.2 & (1.4)^{*} \\
4.9 & (2.7)^{* \dagger}\end{array}$ & $\begin{array}{l}75 \cdot 6(7 \cdot 1) \\
70 \cdot 8(7 \cdot 3) \\
70 \cdot 4(6 \cdot 6)^{*}\end{array}$ & $\begin{array}{l}18 \cdot 0(5 \cdot 4) \\
21 \cdot 0(4 \cdot 8) \\
21 \cdot 1(4 \cdot 5)\end{array}$ & $\begin{array}{l}4 \cdot 1(3 \cdot 5) \\
5 \cdot 1(2 \cdot 7) \\
5 \cdot 3(2 \cdot 4)\end{array}$ & $\begin{array}{l}1.0(0.2) \\
1.3(0.4)^{*} \\
1.2(0.5)^{*}\end{array}$ & $\begin{array}{l}1.3(0.3) \\
1.8(0.6)^{*} \\
1.9(0.5)^{*}\end{array}$ \\
\hline IgM & $\begin{array}{l}\text { C } \\
\text { A } \\
\text { EA }\end{array}$ & $\begin{array}{ll}1.8 & (1.0) \\
1.6 & (1.0) \\
2.3 & (1.9)\end{array}$ & $\begin{array}{l}7 \cdot 1(4 \cdot 0) \\
8 \cdot 0(3 \cdot 9) \\
9 \cdot 5(4 \cdot 2)\end{array}$ & $\begin{array}{l}20 \cdot 5(8 \cdot 7) \\
20 \cdot 2(5 \cdot 7) \\
18 \cdot 6(5 \cdot 0)\end{array}$ & $\begin{array}{l}56.8(8.0) \\
53.4(6.0) \\
51.6(7 \cdot 3)\end{array}$ & $\begin{array}{l}10 \cdot 9(4 \cdot 6) \\
14 \cdot 7(8 \cdot 2) \\
16 \cdot 4(7 \cdot 6)^{*}\end{array}$ & $\begin{array}{l}4.7(3.3) \\
3.7(1.3) \\
3.9(2.7)\end{array}$ \\
\hline
\end{tabular}

* Significantly different from group $C(p<0.05)$.

†Significantly different from group A (p<0

about $75 \%$ of the IgG was found in the $7 \mathrm{~S}$ fraction, with about $20 \%$ in the $8 S-13 S$ fraction, and a small proportion in each of the other fractions. This general pattern was the same for all three groups, but there was a significant decrease in the amount of 7S IgG in group EA and a corresponding increase in the 14S-21S fraction. Group A also had an increase in the 14S-21S fraction, but this was not to the same extent. The absolute values of these increases in immunoglobulin concentrations are greater than might be suggested by the proportionate distributions alone, and represent increased proportions of a larger total immunoglobulin as indicated in the table.

A similar pattern was obtained for $\operatorname{IgA}$ (table 3), except that the increase occurred in the heavier $22 \mathrm{~S}-30 \mathrm{~S}$ fractions, and was similar for both patient groups.

Most of the IgM was detected in the 14S-21S fraction and was distributed similarly for all subjects, though group EA showed a slightly increased proportion in the $22 \mathrm{~S}-30 \mathrm{~S}$ fraction.

Serum RF concentrations were also higher in patients than in controls (table 4, column 3 ). This was so to a much more marked degree than

Table 4 Size distribution of rheumatoid factor $(R F)$ isotypes after sucrose density gradient ultracentrifugation. Values are given as mean (SD)

\begin{tabular}{|c|c|c|c|c|c|c|c|}
\hline \multirow{3}{*}{$\begin{array}{l}\text { Isotype } \\
\text { IgG RF }\end{array}$} & \multirow{3}{*}{$\begin{array}{l}\text { Patient } \\
\text { groupf } \\
\text { C } \\
\text { A } \\
\text { EA }\end{array}$} & \multirow{2}{*}{$\begin{array}{l}\text { Whole serum } \\
\text { concentration } \\
(\mu g / m l)\end{array}$} & \multicolumn{5}{|c|}{ Total $(\mathrm{ng} / \mathrm{ml})$ in gradient zones indicated } \\
\hline & & & $7 S$ & $8 S-13 S$ & $14 S-21 S$ & $22 S-30 S$ & $>30 S$ \\
\hline & & $\begin{array}{ll}0.02 & (0.01) \\
0.63 & (0 \cdot 8)^{*} \\
3 \cdot 2 & (10 \cdot 00)^{*} \dagger\end{array}$ & $\begin{array}{l}6.4(6.9) \\
20.5(41 \cdot 0)^{*} \\
58.7(75 \cdot 8)^{*} \dagger\end{array}$ & $\begin{array}{c}5 \cdot 2(6 \cdot 0) \\
23 \cdot 8(53 \cdot 4)^{*} \\
108 \cdot 4(234 \cdot 5)^{*} \dagger\end{array}$ & $\begin{array}{c}0.4(1 \cdot 3) \\
4 \cdot 2(10 \cdot 4)^{*} \\
144 \cdot 4(146 \cdot 8)^{*}+\end{array}$ & $\begin{array}{l}0 \\
0 \cdot 8(2 \cdot 7)^{*} \\
9 \cdot 6(35 \cdot 3)^{*}\end{array}$ & $\begin{array}{l}0 \\
0 \cdot 5(2 \cdot 5) \\
2 \cdot 2(4 \cdot 0)^{*}\end{array}$ \\
\hline IgA RF & $\begin{array}{l}\text { C } \\
\text { A } \\
\text { EA }\end{array}$ & $\begin{array}{ll}0.003 & (0.005) \\
0.4 & (1.0)^{*} \\
3.2 & (10 \cdot 00)^{*} \dagger\end{array}$ & $\begin{array}{l}0 \\
2 \cdot 4(5 \cdot 1)^{*} \\
29 \cdot 8(144 \cdot 4)^{*}\end{array}$ & $\begin{array}{c}0.01(0.04) \\
24.0(54 \cdot 2) \\
163.5(575 \cdot 0)^{*} \dagger\end{array}$ & $\begin{array}{l}0 \\
14 \cdot 0(40 \cdot 0)^{*} \\
59 \cdot 3(152 \cdot 6)^{*}+\end{array}$ & $\begin{array}{l}0 \\
2 \cdot 0(9 \cdot 5) \\
10 \cdot 1(18 \cdot 6)^{*}\end{array}$ & $\begin{array}{l}0 \\
0 \cdot 1(0 \cdot 7) \\
1 \cdot 3(4 \cdot 0)\end{array}$ \\
\hline IgM RF & $\begin{array}{l}\mathbf{C} \\
\mathbf{A} \\
\mathbf{E A}\end{array}$ & $\begin{aligned} 0 \cdot 1 & (0.01) \\
10 \cdot 0 & (12 \cdot 6)^{*} \\
100 \cdot 0 & (251)^{*} \dagger\end{aligned}$ & $\begin{array}{l}2 \cdot 0(6 \cdot 3) \\
10 \cdot 5(18 \cdot 0)^{*} \\
64 \cdot 5(188 \cdot 4)^{*} \dagger\end{array}$ & $\begin{array}{c}4.0(8 \cdot 4) \\
157 \cdot 3(268 \cdot 2)^{*} \\
1135 \cdot 6(3034)^{*} \dagger\end{array}$ & $\begin{aligned} 20 \cdot 0 & (23 \cdot 1) \\
920 \cdot 4 & (3057 \cdot 1)^{*} \\
4359 \cdot 4 & (12030)^{*} \dagger\end{aligned}$ & $\begin{array}{c}2 \cdot 0(6 \cdot 3) \\
229 \cdot 8(765)^{*} \\
1163.5(3029)^{*} \dagger\end{array}$ & $\begin{array}{l}0 \\
22 \cdot 6(66 \cdot 4)^{*} \\
80 \cdot 4(193 \cdot 2)^{*} \dagger\end{array}$ \\
\hline
\end{tabular}


with total immunoglobulin. In control subjects the IgG RF was distributed about equally between the 7S and 8S-13S fractions. In group A there was slightly more in the $8 \mathrm{~S}-13 \mathrm{~S}$ fractions, while in group EA there was a very significant increase in the 8S-13S fraction. In the higher molecular weight fractions there was a slight increase in IgG RF in group A but once again a large increase in group EA.

In those few control subjects who had detectable concentrations of IgA RF it was present in fraction 8S-13S. Both patient groups had clearly raised concentrations in all fractions, especially in the 8S-13S and 14S-21S fractions.

IgM RF occurred almost entirely in the 14S-21S fraction in group C but was also present in substantial amounts in the 22S-30S and $>30 S$ fractions for both patient groups.

The figure provides a summary of the

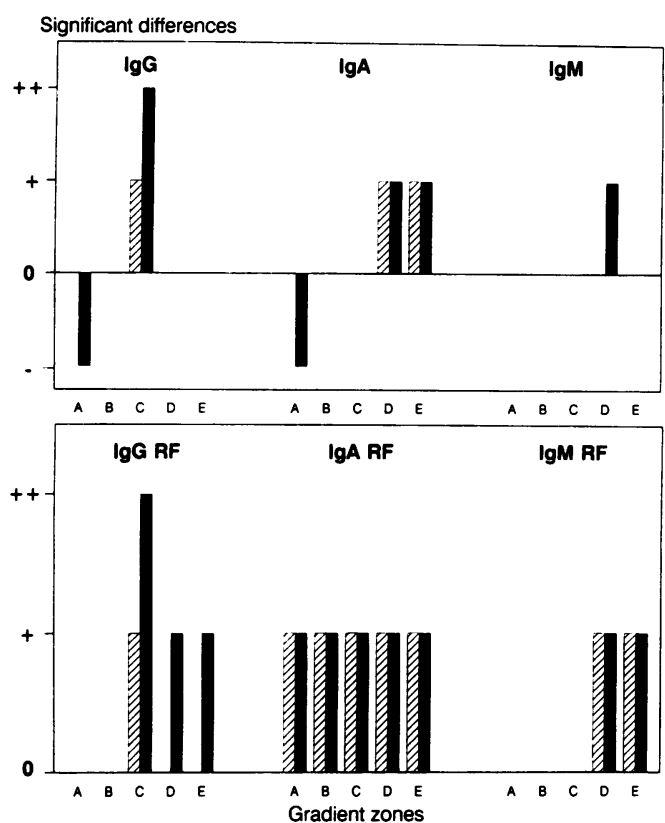

Significant differences between patients and controls in concentrations of immunoglobulins and rheumatoid factors of different sizes. Analysis of the results of immunoglobulin and rheumatoid factor measurements (expressed as percentage of total immunoglobulin and rheumatoid factor contents of the gradient fractions) in the gradient zones using one way analysis of variance. The findings are presented as $(0)$ when no differences were noted; $(-)$ for significantly lower concentrations; $(+)$ for significantly higher concentrations $(p<0.05)$, and $(++)$ for very significantly higher values $(p<0.01)$ in the gradient zones for the patient groups compared with controls. The zones are presented as $A(7 S)$; $B(8 S-13 S) ; C(14 S-21 S) ; D(22 S-30 S)$, and $E(>30 S)$ $\square=$ patients with articular disease; $\square=$ patients with extra-articular disease. immunoglobulin and RF results, where only the significant differences between the patient and control groups have been plotted. In general, IgG concentrations were increased in the middle range fractions in group $A$ patients and more so in group EA patients. For IgA both patient groups showed increases in the heavier fractions. Concentrations of IgM showed little change from normal.

Rheumatoid factor concentrations, as well as being much greater in the patient groups in absolute values, also showed a difference in distribution according to the density gradient fractions. Whereas both patient groups had increased proportions of IgM RF in the heavy fractions, and both showed increases in IgG RF in the 14S-21S fraction, only group EA patients showed the presence of IgG RF in significant amounts in the heavy fractions (22S-30S and $>30$ S).

The nature of immunoglobulins and RFs in heavy molecular weight fractions was also examined by centrifugation on acid gradient. Serum samples from 16 patients (four from group A and 12 from group EA) were fractionated simultaneously on both phosphate buf-

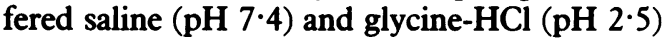
gradients. The mean concentrations of IgG (table 5) were significantly increased in the 7S zone and decreased in the 8S-13S and 14S-21S zones for both groups of patients. The concentrations of IgG RF showed a significant increase in the 8S-13S zone only for patients of group A. In marked contrast, in patients from the EA group a significant increase in the concentration of IgG RF was noticed in the $7 S$ zone. This was paralleled by a highly significant reduction in IgG RF in the high molecular weight zones. Similar results were noted for IgA RF and IgM RF (results not presented).

\section{Discussion}

Previous studies have shown the importance of size in determining the pathogenicity of circulating immune complexes in human immune complex disease and in animal models. ${ }^{12} 13$ In this study using ultracentrifugation and class specific ELISA for immunoglobulins and RF we showed an association between large size IgG RF-IgM RF complexes and extra-articular features of RA.

The results show that in general circulating immune complexes in RA may be broadly grouped into small (8S-13S), intermediate

Table 5 Size distribution of $I g G$ and $I g G$ rheumatoid factor $(R F)$ after sucrose density gradient: effect of acid dissociation. Results are given as mean (SD)

\begin{tabular}{|c|c|c|c|c|c|c|c|}
\hline & \multirow{2}{*}{$\begin{array}{l}\text { Patient } \\
\text { groupt }\end{array}$} & \multirow[t]{2}{*}{$p H$} & \multicolumn{5}{|c|}{ Proportion (\%) in gradient zones indicated } \\
\hline & & & $7 S$ & $8 S-13 S$ & $14 S-21 S$ & $22 S-30 S$ & $>30 S$ \\
\hline IgG & $\begin{array}{l}\text { A } \\
\text { EA }\end{array}$ & $\begin{array}{l}7 \cdot 4 \\
2 \cdot 5 \\
7 \cdot 4 \\
2 \cdot 5\end{array}$ & $\begin{array}{l}67 \cdot 1(9 \cdot 4) \\
82 \cdot 2(6 \cdot 2)^{*} \\
71 \cdot 8(7 \cdot 8) \\
80 \cdot 0(4 \cdot 6)^{* *}\end{array}$ & $\begin{array}{l}26 \cdot 1(7 \cdot 2) \\
13.0(5 \cdot 5)^{*} \\
20 \cdot 7(6 \cdot 2) \\
14 \cdot 5(4 \cdot 3)^{* *}\end{array}$ & $\begin{array}{l}4 \cdot 5(3 \cdot 5) \\
2 \cdot 2(1 \cdot 2)^{*} \\
4 \cdot 6(2 \cdot 5) \\
2 \cdot 2(0 \cdot 9)^{* *}\end{array}$ & $\begin{array}{l}1.0(0.2) \\
0.7(0.1) \\
1.2(0.8) \\
0.8(0.2)\end{array}$ & $\begin{array}{l}1.3(0.4) \\
1.7(0.2) \\
1.0(0.3) \\
1.4(0.3)\end{array}$ \\
\hline IgG RF & $\begin{array}{l}\text { A } \\
\text { EA }\end{array}$ & $\begin{array}{l}7 \cdot 4 \\
2 \cdot 5 \\
7 \cdot 4 \\
2 \cdot 5\end{array}$ & $\begin{array}{l}61.3(11.6) \\
52.6(16.9) \\
50.2(23.9) \\
74.9(12.7)^{* *}\end{array}$ & $\begin{array}{l}24.9(4 \cdot 3) \\
43.8(19 \cdot 5)^{* *} \\
27 \cdot 5(11.6) \\
16.7(8.6)^{* *}\end{array}$ & $\begin{array}{c}2 \cdot 0(2 \cdot 3) \\
2 \cdot 0(0 \cdot 7) \\
14 \cdot 2(16 \cdot 2) \\
5 \cdot 2(3 \cdot 8)^{*}\end{array}$ & $\begin{array}{l}1 \cdot 1(1 \cdot 3) \\
0 \cdot 9(0 \cdot 5) \\
7 \cdot 8(1 \cdot 2) \\
1 \cdot 2(1 \cdot 1)^{*}\end{array}$ & $\begin{array}{l}1.7(1.9) \\
1.2(1.3) \\
4.9(5 \cdot 7) \\
1.7(1.1)^{*}\end{array}$ \\
\hline
\end{tabular}

Significantly different from content of the same zone at $\mathrm{pH} 7 \cdot 4:{ }^{*} \mathrm{p}<0.05 ;{ }^{* *} \mathrm{p}<0.01$

$+A=$ patients with articular disease; $E A=$ patients with extra-articular disease. 
(14S-21S), and large ( $>22 S)$ sizes. About half of all the patients with RA studied had small size complexes. Such complexes are likely to be composed of dimers of self associated IgG RF or one IgG RF complexed to a normal IgG molecule.

Intermediate size IgG complexes (14S-21S) are composed of three to five molecules of IgG and are likely to be arranged in the form of a tetramer of two molecules of self associated IgG RF and two normal IgG molecules according to the theoretical model of Nardella et al. ${ }^{26}$ IgG RF tends to self associate preferentially as thermodynamics favour the formation of two antigenantibody bonds rather than one. Further polymerisation of self associated IgG RF will proceed with a comparable free energy to that of normal IgG binding. Thus normal IgG will bind to a dimer of self associated IgG RF in preference to other IgG RFs owing to its relatively high concentration in serum and hence the effect of mass action, so effectively terminating further polymerisation and resulting in tetrameric complexes. The increase in RF complexes reported here may result from the higher concentration of IgG RF found in the serum of patients with extra-articular features compared with articular RA. More IgG RF will therefore be available to bind to the self associated IgG RF dimers. Large size complexes $(22 \mathrm{~S}-30 \mathrm{~S}$ and $>30 \mathrm{~S})$ were characteristically found in the serum of patients with extraarticular features of RA. These complexes are apparently composed of IgG RF dimers polymerised further with other IgG RF molecules. In contrast with intermediate size IgG tetramers such polymers have exposed antigenic sites and thus bind to IgM RF. ${ }^{26}$

Analysis of the serum samples under dissociating conditions using glycine- $\mathrm{HCl}$ gradients showed that the high molecular weight IgG RF was in the form of immune complexes rather than aggregates as aggregated IgG cannot be dissociated under the same conditions. ${ }^{27}$ Furthermore, the pattern of change of the concentration of IgG and IgG RF supported our hypothesis about the nature of complexes in patients with extra-articular disease. Whereas there is a substantial rise in the concentration of dimeric (8S-13S) IgG RF in patients with articular disease (group A) after acid dissociation, the rise in concentration of IgG RF in patients with extra-articular disease (group EA) was mainly noted in the $7 \mathrm{~S}$ zone under the same conditions.

Complexes of IgM RF and polymers of IgG RF will form in preference to complexes between IgM RF and normal IgG owing to the low affinity of IgM RF for monomeric IgG and its high avidity for aggregated IgG. ${ }^{28}$

Previous studies have suggested the association of high concentrations of IgG RF with extra-articular features of RA. ${ }^{29}$ The precise mechanism by which IgG RF may contribute to the pathogenesis of extra-articular features, and vasculitis in particular, in patients with RA was not clear. Whereas small size circulating immune complexes are apparently of no pathogenic significance in synovitis, the formation of large complexes of IgM RF and polymers of IgG
RF reported here can initiate pathogenic mechanisms which contribute to vasculitis. ' Large size IgG RF complexes enhance platelet aggregation, ${ }^{30}$ leading to the release of vasoactive amines and histamine, which in turn increases vascular permeability resulting in the trapping of complexes along the basement membrane. ${ }^{12}$ Furthermore, although IgM RF containing complexes inhibit platelet aggregation, ${ }^{30} \mathrm{IgM}$ RF may nevertheless enhance complement activation by IgG RF complexes and reduce solubilisation of such complexes. ${ }^{31}$

The significance of circulating immune complexes containing $\operatorname{IgA}$ in the sera of many patients with $R A$, and of dimeric $\operatorname{IgA} R F$ detected in the sera of patients with extraarticular features, remains to be elucidated. Recent studies link increased concentrations of IgA RF with fluctuation of disease activity, poor prognosis, and the development of erosions. ${ }^{32-34}$ Our results also show that IgA RF in RA occurs mainly in the form of polymers. Similar findings were reported for IgA RF in patients with sicca syndrome. ${ }^{35}$ Longitudinal studies on patients measuring the size of their circulating immune complexes before and after the development of extra-articular features may provide additional evidence as to the pathogenic role of IgA RF complexes.

The authors thank Professor H L F Currey, Drs J D Perry, (department of rheumatology, The London Hospital), Dr C Corke (York), and Dr A Kirk (Norwich) for providing serum samples from patients in their care, and Mr S Moore (school of biological sciences, Queen Mary College) for his excellen technical help in performing the sucrose density ultracentrifugation.

The support of the Arthritis and Rheumatism Council for J R Kirwan and R A K Mageed is gratefully acknowledged.

1 McDougal J S, McDuffie F C. Immune complexes in man: detection and clinical significance. Adv Clin Chem 1985; 24: $1-60$.

2 Korbet $S M$, Schwartz M M, Lewis E J. Immune complex deposition and coronary vasculitis in systemic lupus erythematosus. Am $\mathcal{F}$ Med 1984; 77: 141-6.

3 Munthe E, Natvig J B. Characterization of IgG complexes in eluates from rheumatoid tissue. Clin Exp Immunol 1971; 8: 249-62.

4 Kinsella T D, Baum J, Ziff M. Immunofluorescent demonstration of an IgG-Blc complex in synovial lining cells of rheumatoid synovial membrane. Clin Exp Immunol 1969; 4 265-71.

5 Kunkel H G, Muller-Eberhard H J, Fudenberg H H, Tomasi T B. Gamma globulin complexes in rheumatoid arthritis and certain other conditions. F Clin Invest 1961; 40: and certain.

6 Zvaifler N J. Rheumatoid synovitis: an extravascular immune complex disease. Arthritis Rheum 1974; 17: 297-305

7 Franklin E C, Holman H R, Muller-Eberhard H J, Kunkel H G. An unusual protein component of high molecular weight in the serum of certain patients with rheumatoid arthritis. J Exp Med 1957; 105: 425-38.

8 Zubler R H, Nydegger U, Perrin L H, et al. Circulating and intra-articular immune complexes in patients with rheumatoid arthritis. F Clin Invest 1976; 57: 1308-19.

9 Gupta R C, McDuffie F C, Huston K A, et al. Comparison of three immunoassays for immune complexes in rheumatoid arthritis. Arthritis Rheum 1979; 22: 433-9.

10 Halla J T, Volanakis J E, Schrohenloher R E. Immune complexes in rheumatoid arthritis sera and synovial fluids. A comparison of three methods. Arthritis Rheum 1979; 22: A compari.

11 Urowitz M B, Gordon D A, Broder I. Studies into the occurrence of soluble antigen-antibody complexes in occurrence of soluble antigen-antibody complexes in
disease. V-Second assessment of correlation between rheumatoid biologically active factor (RBAF) and the clinical features of rheumatoid arthritis. Arthritis Rheum clinical features of

12 Cochrane C G, Hawkins D. Studies on circulating immune complexes-III. Factors governing the ability of circulating complexes to localize in blood vessels. $\mathcal{F}$ Exp Med 1968 127: 137-54. 
13 Levinsky R J, Cameron J S, Soothill J F. Serum immune complexes and disease activity in lupus nephritis. Lancet 1977; i: $564-7$.

14 Tung K S K, DeHoratius R J, Williams R C Jr. Study of circulating immune complex size in systemic lupus erythematosus. Clin Exp Immunol 1981; 43: 615-25.

15 Winchester R J, Agnello V, Kunkel H G. Gamma globulin complexes in synovial fluids of patients with rheumatoid arthritis. Partial characterization and relationship to lowered complement levels. Clin Exp Immunol 1970; 6: lowered $689-706$.

16 Stanworth D R, Johns P. Ultracentrifugal methods of detecting soluble immune complexes. Ann Rheum Dis 1977; 36 (suppl): 12-16.

17 Pope R M. Teller D C, Mannik M. The molecular basis of self-association of antibodies to IgG (rheumatoid factor) in rheumatoid arthritis. Proc Natl Acad Sci USA 1974; 71: 517-21.

18 Moller N P H, Kallerup H E, Linnet L. Demonstration and characterisation of immune complexes formed in vitro and in patients with rheumatoid arthritis: sucrose density gradient ultracentrifugation. Protides of the Biological Fluids 1979; 27: 857-62.

19 Ropes M W Bennett G A, Cobb S, Jacox R, Jessar R A. Revision of diagnostic criteria for rheumatoid arthritis. Revision of diagnostic criteria

20 Zubler R H, Lange G, Lambert P H, Miescher P A. Detection of immune complexes in unheated sera by modified ${ }^{125} \mathrm{I}-\mathrm{Clq}$ binding test. Effect of heating on the binding of Clq by immune complexes and application of the test to systemic lupus erythematosus. $\mathcal{F}$ Immunol 1976; 116: $232-5$.

21 Bourke B E, Moss I K, Mumford P, Horsfall A, Maini R N. The complement fixing ability of putative circulating immune complexes in rheumatoid arthritis and its relationship to extra-articular disease. Clin Exp Immunol 1982; 48: 726-32.

22 Hay F C, Nineham L J, Roitt I M. Routine assay for the detection of immune complexes of known immunoglobulin class using solid phase Clq. Clin Exp Immunol 1976; 24: class using

23 Wager $\mathrm{O}$, Lindstrom $\mathrm{P}$, Rasanen J A, et al. Evaluation of six tests for circulating-IgG complexes with special reference to IgM rheumatoid factors: analysis of systemic lupus erythematosus and rheumatoid arthritis series. Clin Exp Immunol 1981; 46: 149-60.

24 March R E, Reeback J S, Holborow E J, Jones V E, Jacoby
R K. The complement fixing properties and class distribution of rheumatoid factor (antiglobulins in rheumatoid arthritis and other diseases). Clin Exp Immunol 1982; 48: $555-60$.

25 McCarthy D, Goddard D H, Holborow E J, Horsfall A C, Mumford P A, Maini R N. The effect of IgG aggregate size and concentration on reactivity in immune complex assays. 7 Immunol Methods 1981; 47: 349-58.

26 Nardella F A, Teller D C, Mannik M. Studies on the antigenic determinants in the self-association of IgG antigenic determinants in the self-association

27 Benveniste J, Bruneau C. Detection and characterization of circulating immune complexes by ultracentrifugation. $\mathfrak{f}$

28 Isenberg $R$. The specificity and polyvalency of binding of a monoclonal rheumatoid factor. Immunochemistry 1976; 13: 355-9.

29 Scott D G I, Bacon P A, Allen C, Elson C J, Wallington T. IgG rheumatoid factor, complement and immune complexes in rheumatoid synovitis and vasculitis: comparative and serial studies during cytotoxic therapy. Clin Exp Immunol 1981; 43: 54-63.

30 Fink P C Piening U, Fricke $M$, Deicher $H$. Platelet aggregation and aggregation inhibition by different antiaggregation and aggregation inhibition by different antiwith rheumatoid arthritis. Arthritis Rheum 1979; 22: with rhe 903 .

31 Dayer E, Gerster J C, Aguado M T, Lambert P H. Capacity to solubilize immune complexes in sera and synovial fluids from patients with rheumatoid arthritis. Arthritis Rheum 1983; 26: 156-64.

32 March R E, Kirwan J R, Reeback J S, Holborow E J. IgM, IgG and IgA rheumatoid factors (antiglobulins) in early
rheumatoid arthritis and their prediction of articular index over one year. Scand ₹ R heumatol 1987; 16: 407-11.

33 Teitsson I, Withrington R H, Seifert M H, Valdimarsson $H$ Prospective study of early rheumatoid arthritis. I. Prognostic value of IgA rheumatoid factor. Ann Rheum Dis 1984; 43: 673-8.

34 Withrington $R$ H, Teitsson I, Valdimarsson $H$, Seifert $M H$. Prospective study of early rheumatoid arthritis. II. Association of re study of early rheumatoid arthritis. II. Association of rheumatoid factor isotypes with fluctuation
disease activity. Ann Rheum Dis 1984; 43: 679-85.

disease activity. Ann Rheum Dis 1984; 43: 679-85.
35 Elkon K B. Delacroix D L, Gharavi A E, Vaerman J P, Hughes G R V. Immunoglobulin A and polymeric IgA rheumatoid factors in systemic sicca syndrome: partial characterisation. F Immunol 1982; 129: 576-81. 